by Inna Safonova ${ }^{1,2}$, Reimar Seltmann ${ }^{3}$, Min Sun $^{4}$, Wenjiao Xiao $^{5,6}$, Sergei Rasskazov ${ }^{7}$, Evgeny Kislov ${ }^{8}$, Sung Won Kim ${ }^{9}$, Dick Glen ${ }^{10}$

\title{
Continental Construction in Central Asia (IGCP\#592): 2013 Meetings and Training Activities
}

\author{
1 Institute of Geology and Mineralogy SB RAS, Koptyuga ave. 3, Novosibirsk, 630090, Russia. E-mail: \\ 2 Novosibirsk State University, Pirogova St. 2, Novosibirsk, 630090, Russia \\ 3 Centre for Russian and Central EurAsian Mineral Studies (CERCAMS), Natural History Museum, Cromwell Road, London SW7 5BD, UK \\ 4 Department of Earth Sciences, the University of Hong Kong, Pokfulam Road, Hong Kong, China \\ 5 Xinjiang Research Center for Mineral Resources, Xinjiang Institute of Ecology and Geography CAS, Urumqi 830011, China \\ 6 State Key Laboratory of Lithospheric Evolution, Institute of Geology and Geophysics CAS, Beijing, 100029, China \\ 7 Institute of Earth Crust SB RAS, Lermontova Ave. 128, 664033, Irkutsk, Russia \\ 8 Geological Institute SB RAS, Sakhyanova Str. 6a, Ulan-Ude 670047, Russia \\ 9 Korea Institute of Geoscience and Mineral Resources, 124 Gwahang-no, Daejeon, 305-350, South Korea \\ 10 GEMOC, Department of Earth and Planetary Sciences, Macquarie University, Sydney, NSW 2109, Australia
}

The meeting program of the second year of IGCPProject \#592 (2012-2015) "Continental construction in the Central Asian Orogenic Belt compared to actualistic examples from the western Pacific" funded by UNESCOIUGS included five international conferences and workshops in Russia, China, South Korea and New Zealand. This report summarizes the main topics and scientific results of the meetings. In addition, the IGCP\#592 program included several training schools for young scientists and special training courses in Japan, Kazakhstan, Russia, South Korea, and Uzbekistan. Since 2013, more than two hundred scientists from 35 countries expressed their interest in collaborating in our Project, of which more than 30\% were women and young scientists. Participants come from Australia, Austria, Bangladesh, Belgium, China, Czech Republic, France, Germany, India, Indonesia, Iran, Israel, Japan, Kazakhstan, Kyrgyzstan, Madagascar, Malaysia, Mongolia, Myanmar, Nepal, Netherlands, New Zealand, Norway, Poland, Russia, South Africa, South Korea, Switzerland, Taiwan, Tajikistan, Thailand, United Kingdom, USA, Vietnam and Uzbekistan. In order to carry out research and to secure meeting activities, project participants received funding from national and international foundations and mining companies. We also present a schedule and major topics of IGCP\#592 associated meetings planned for 2014.

\section{Introduction}

During the second year of project activities, IGCP\#592 was a co-organizer and/or co-sponsor of five international meetings (Safonova et al., 2013). This allowed us to continue the successful course of the Project and to attract more participants, especially young scientists and scientists from Central Asian developing countries. In addition to the major goals of our project, i.e. the presence/absence of Gondwana-derived terranes in the Central Asian Orogenic Belt (CAOB), proportions of juvenile and recycled continental crust, and the general comparison with the Western Pacific (Safonova et al., 2011), in 2013 our activities were focused on (i) accretion as part of continental construction; (ii) proportion of accretionary (Pacifictype) and collisional (Alpine-type) orogenic belt in the CAOB; (iii) combination of $\mathrm{U}-\mathrm{Pb}$ zircon ages with $\mathrm{Nd}$ and $\mathrm{Hf}$ isotopes for elucidation of magma source characteristics; (iv) formation of PGE and copper porphyry deposits during crustal growth. In this report we summarize our scientific meetings and review the related field trips and training/lecture courses for young scientists. Finally, we advertise our meetings scheduled for 2014. In total, participants from 35 countries joined IGCP\#592 related meetings and field visits in 2013 (Australia, Austria, Bangladesh, Belgium, China, Czech Republic, France, Germany, India, Indonesia, Iran, Israel, Japan, Kazakhstan, Kyrgyzstan, Madagascar, Malaysia, Mongolia, Myanmar, Nepal, Netherlands, New Zealand, Norway, Poland, Russia, South Africa, South Korea, Switzerland, Taiwan, Tajikistan, Thailand, United Kingdom, USA, Vietnam and Uzbekistan). All materials related to project performance (original application, flyers, circulars, pdf-files of meeting proceedings, photo reports, sponsors, etc.) are available at our website: http://igcp592.igm.nsc.ru.

\section{Meeting \#1: "Continental rifting and accompanying processes"}

A Symposium and Training School for Young Scientists on "Continental rifting and accompanying processes" was held on August 20-23, 2013 and organized by the Institute of the Earth's Crust SB RAS, Irkutsk, Russia (http://izk.irkmail.ru/ieng.html). The aims of the symposium were (i) to highlight problems of Cenozoic rifting and its linkage with the whole geological history of continents; (ii) to 
discuss processes of continental rifting resulting in extension and thinning of the lithosphere; (iii) to provide an IGCP592-based forum for discussions on the links between rifting and volcanism, hydrothermal activity, tectonics, sedimentation, and formation of valuable mineral deposits. The scope of the meeting was concentrated on Siberia (with a focus on Transbaikalia), Kyrgyzstan, Mongolia and China.

The meeting brought together leading and young scientists from Belgium, China, Israel, Kyrgyzstan, Mongolia, Russia, USA and Vietnam: over 100 participants with about $30 \%$ of young scientists. It was a successful forum for discussions about the rifting in the $\mathrm{CAOB}$ and adjacent areas. The program included 83 oral talks in six sessions: (1) Evolution of processes related by continental rifting in the Earth's history; (2) Stratigraphy, lithology and geochronology of sedimentary and volcanogenic-sedimentary series in continental rifts; (3) Conditions of formation of carbohydrate and other mineral deposits in the rift structures; (4) Monitoring of modern processes in the areas of continental rifting, prognosis of geological hazards; (5) Mantle and crust of rift zones; (6) Geodynamic models. The participants discussed (i) origin and evolution of continental rift systems in East Asia, (ii) rift origin of intracontinental basins with anomalously thin consolidated crust, (iii) the Baikal versus East African versus Shanxi rifts; (iv) rifting-related tectonics and seismicity, (v) plume-related rifting and volcanism (Rasskazov et al., 2013). Of special importance were contributions on the formation of mineral deposits in rift systems. During the post-conference field trip to the Baikal area (Fig. 1a) the participants observed outcrops of the NE-trending Main Sayan fault separating the Neoarchean Sharyzhalgay uplift of the Siberian platform and the Slyudyanka metamorphic complex (Kröner et al., 2014).

\section{Meeting \#2: "Beishan Orogen in NW China"}

An International Field Trip and Workshop entitled "Beishan Orogen in NW China: accretionary tectonics, magmatism, eclogite and granulite complexes" were held on August 22-28, 2013, HamiDunhuang, NW China, organized by the Institute of Geology and Geophysics (Beijing) and Institute of Geography and Ecology (Urumqi) of the Chinese Academy of Sciences (http://www.igg.cas.cn/ hejl/jldt/201310/t20131008_3944169.html). This was a focus meeting organized solely by IGCP\#592, which included a field trip to the Beishan Orogen (4 days), two days of scientific sessions before and after the field trip, and several en-route discussions. The main goal of the meeting was to integrate previous and recent field observations and laboratory analyses and to discuss the tectonic evolution of the Beishan Orogen, which is crucial for a better understanding the history of the southern CAOB. The specific objectives were to understand the accretionary structures and subduction-related magmatism, to study the geological implications of eclogites and granulites, and to unravel the accretionary tectonics and temporal-spatial characteristics of the southern CAOB.

The Workshop attracted about 40 participants and paper authors from 17 countries, namely Australia, Bangladesh, Belgium, China, Czech, France, Germany, Japan, Kyrgyzstan, Mongolia, Norway, Poland, Russia, South Africa, Thailand, UK, and Uzbekistan. The participants gave 21 oral and 3 poster presentations in two sessions: (1) Beishan Orogen and other examples from Eurasia and Australia; (2) the Central Asian Orogenic Belt and western Pacific. During the field trip the participants visited (i) the Middle Triassic, NE-striking
Xingxingxia sinistral ductile shear zone; (ii) late Ordovician Nbenriched basalts and dacites, late Silurian and early Devonian adakites and I-S-A-type granites (436 Ma-380 Ma); (iii) the Permian-Middle Triassic Pochengshan thrust belt; (iv) the Late Permian-Middle Triassic Hongyanjing superposed folding; (v) the Gubaoquan locality of Ordovician eclogites; (vi) the Shibaocheng locality of Paleoproterozoic tonalitic gneisses and Early Paleozoic mafic granulites and garnet amphibolites (Xiao et al., 2013). Participants also discussed the geological structure, tectonics, stratigraphy and magmatism of the Beishan Orogen (e.g., Song et al., 2013; Tian et al., 2013), in particular, the collision-type PT-path of the Gubaoquan eclogites (Fig. 1b) with oceanic protolith and the remnants of Oceanic Plate Stratigraphy (OPS; pillow-lavas, chert; Kusky et al., 2013) preserved in the Shibaocheng granulites.

\section{Meeting \#3: "Geodynamics and metallogeny of NE Asia"}

The IV Conference «Geodynamics and metallogeny of NE Asia» was held on August 27-31, 2013, and organized by the Institute of Geology SB RAS, Ulan-Ude, Russia (http://geo.stbur.ru/doc/circular2013-08-2.pdf). The program included scientific sessions and a 3day field trip. The sessions were: (i) tectonics, magmatism and geodynamic evolution of the Siberian Craton and its folded frame: implications from petrologic, geochemical, geochronological and geophysical data; (ii) geochemistry and mineralogy of ore deposits formed indifferent tectonic settings; formation of giant deposits; ore mineralization through magmatism, metamorphism and metasomatism; (iii) tectonics and seismicity of the Baikal Region inferred from experimental modeling of natural and anthropogenic systems; (iv) environmental and climate changes; mining impact on the ecology of Lake Baikal.

About 80 researchers from Mongolia, Poland, Russia and Vietnam presented 75 oral talks and 35 posters. The major talks/papers were (1) Paleo-Asian Ocean ophiolites; (2) Neoproterozoic and Paleozoic subduction systems of the Paleo-Asian and Mongol-Okhotsk oceans at the southern active margins of the Siberian Craton; (3) intra-plate magmatism in Transbaikalia and Mongolia and its related metallogeny; (4) tectonics and metallogeny of the Mongol-Okhotsk orogen (eastern CAOB); (5) the Khangai batholith (southern CAOB): a type locality of granitoid magmatism; (6) seismic heterogeneity of the upper mantle beneath the Siberian Craton; (7) the microcontinent versus active margin nature of the Olkhon composite terrain at the southern frame of the Siberian craton (Tsygankov and Kislov, 2013). The meeting program included three field trips in Transbaikalia (Fig. 1c). During the first field trip the participants examined the Ozernoye $\mathrm{Pb}-\mathrm{Zn}$ deposit hosted by Cambrian breccia, limestone and tuff. The second field trip visited the Bilyuta limestone mine, which exposes numerous sub-nearly parallel dikes, which can be traced over $200 \mathrm{~km}$. They dikes may be related to the crust extension induced by the intrusion of the giant Angara-Vitim batholith of Carboniferous age. The third target was the Arsentiev Fe-Ti-V deposit hosted by an Early Permian gabbro-syenite massif.

\section{Meeting \#4 "Gondwana to Asia"}

The 2013 IAGR Annual Convention and $10^{\text {th }}$ International Symposium on "Gondwana to Asia" and IGCP 592 were organized by the Korea Institute of Geoscience and Mineral Resources (KIGAM) 

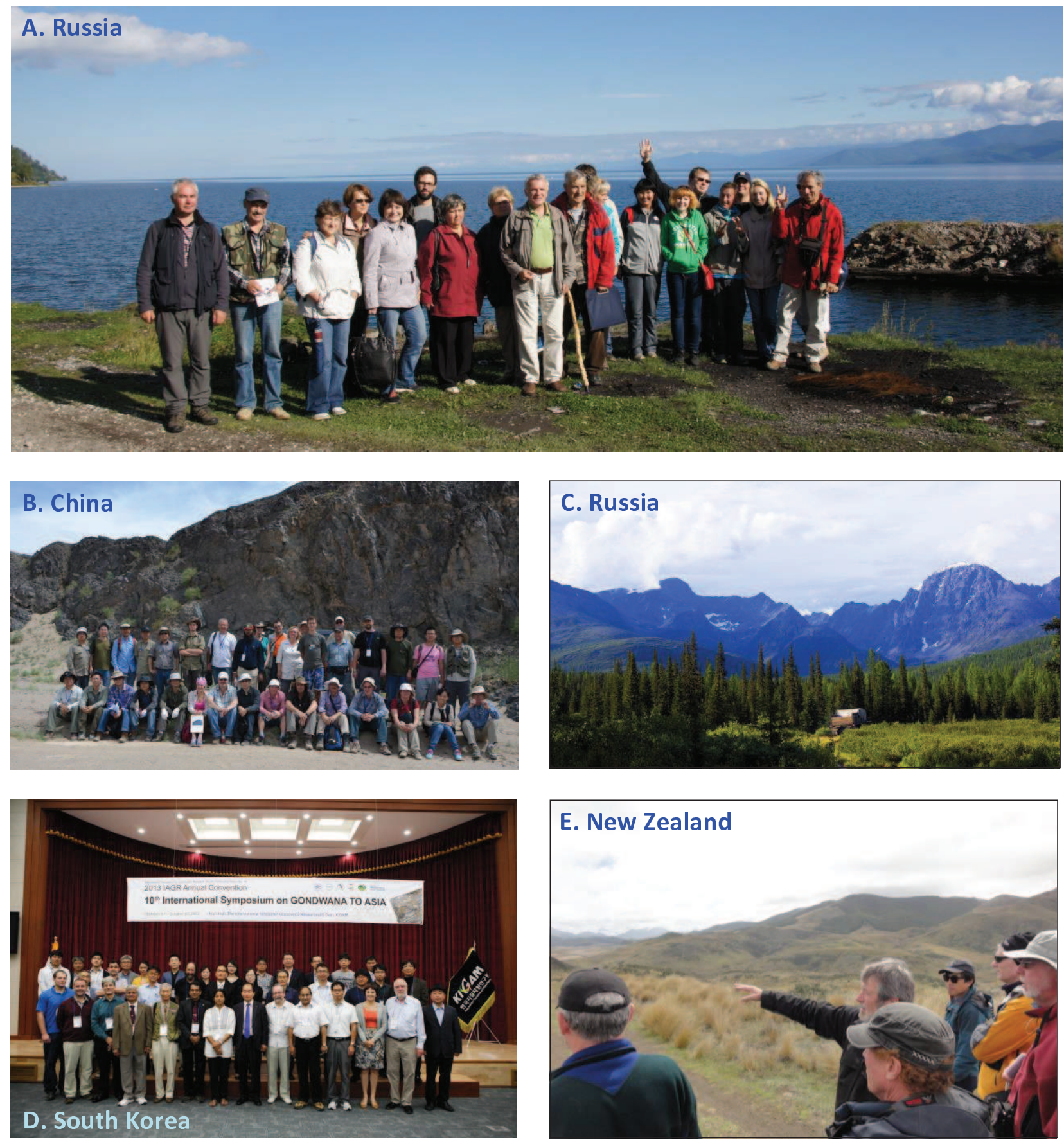

Figure 1. Conference and field photos from the 2013 activities of IGCP\#592: (a) post-conference trip to the Baikal area, Russia, led by Sergei Rasskazov, left center (Meeting\#1); (b) field trip to the Beishan Orogen, NW China, led by Wenjiao Xiao; the Gubaoquan eclogite locality (Meeting\#2); (c) the Neoproterozoic Inyaptuk massif, Transbaikalia, Russia, which origin was discussed during Meeting \#3, the photo was made during a field trip led by Evgeny Kislov; d) group photo from the 2013 IAGR Symposium in "Gondwana to Asia" in KIGAM (Meeting\#4); (e) post-conference field trip in the South Island of New Zealand (Meeting \#5): Hamish Campbell (trip co-leader) pointing out the faulted boundary between the Murihiku and Brook Street terranes; the other co-leader, Nick Mortimer, is at the left.

on September 30 - October 3, 2013, in Daejeon-HongseongAnmyeon-do, South Korea (http://iagr2013.kigam.re.kr). The focuses of the meeting were Earth System Dynamics, Geology and Tectonic evolution of Gondwana Break-up and the assembly of Asia, Geology and Tectonic evolution of the Korean Peninsula and East Asia (Kim and Park, 2013). The program included (i) oral and poster presentations on three sessions: "Continental tectonics: structure and evolution"; "Magmatic activity, economic geology and natural resources"; "Sedimentary basin evolution and paleogeography"; (ii) post conference field trip to the Gyeonggi massif and Imjingang belt; (iii) Best-Poster Challenge for young scientists; (iv) Annual Meeting of Gondwana Research (GR) Editorial Board and International Association of Gondwana Research (IAGR) Secretariat (Lee and Kim, 2014).

About 140 participants and paper authors from 14 countries (Australia, China, India, Indonesia, Japan, South Korea, Madagascar, 
Mongolia, Nepal, Russia, South Africa, Switzerland, Thailand, USA) presented 36 oral and 29 poster presentations (Fig. 1d). The GRIAGR meeting discussed the annual results of GR and IAGR activity. The participants of the post-conference field excursion examined the lithology, structure and metamorphic architecture of the Wonnojeon Neoproterozoic A-type granite and serpentinite; Deokjeongri Neoproterozoic tonalite and granodiorite (orthogneiss); Wolhyeonri complex of Paleozoic metavolcanic rocks; Taean Formation of Paleozoic low to medium grade metasedimentary rocks; Gonam complex of Paleoproterozoic to Triassic highly deformed metaplutonic and metasedimentary rocks. The hottest discussions were on the Columbia versus North China versus active margin origin of the Okcheon belt of South Korea and its affinity to the CAOB. Scientific contributions covered all the continents in Australia, India, China and Russia, including Central Asia, as well as orogenic processes in the regions.

\section{Meeting \#5: "Accretionary orogens of the SW Pacific"}

A special session associated with IGCP\#592 was organized as a part of the 2013 Annual Conference of the Geoscience Society of New Zealand (GSNZ). The meeting was held on November 24-27, 2013 at the: University of Canterbury, Christchurch, New Zealand, and included a field trip with itinerary: Christchurch-GeraldineQueenstown-Te Anau-Invercargill-Dunedin (Fig. 1e) (http://www. cvent.com/events/geosciences-2013-conference/event-summary5cb5c6cf843848df87f293052ac744e0.aspx). The GSNZ-IGCP 592 symposium "Accretionary orogens of the SW Pacific: models for the Central Asian Orogenic Belt?" allowed contributors to discuss the origin and tectonics of Phanerozoic accretionary complexes and igneous rocks from both the New Zealand-SW Pacific region and from the CAOB. A key reason for IGCP's involvement was the fieldtrip across the New Zealand's Mesozoic accretionary orogen (see below).

In the conference session, participants discussed oceanic plate stratigraphy, tectonic accretion versus erosion during subduction, subduction-related magmatism, syn- and post-accretion deformation, sediment provenance and mineral resources. Focuses were to the accretionary orogen of the Tasmanides of Eastern Australia (Glen, 2013), Cambrian to Holocene stratigraphic framework for Zealandia, the Chatham Rise margin of Zealandia and the Cretaceous Shimanto accretionary belt in southwestern Japan. The post-conference field trip led by N. Mortimer and H. Campbell of GNS Science New Zealand covered the latest interpretations of the Mesozoic orogen Zealandia. Critical aspects covered were the relationships between arcs (Median Batholith and Brook Street), the Muruhiku forearc basin, the Dun Mountain Ophiolite and the overlying Maitai Terane, and the different types of accretionary complexes represented, by the Caples Terrane and the Torlesse (e.g., Mortimer et al., 1999). Also discussed were the extensional and progressive contractional deformations in the Otago Schist, formed by 'collision' of the Caples and Torlesse terranes and the importance of provenance. The meeting helped to promote the new IGCP-592 project and to win new participants.

\section{IGCP\#592 related educational and training activities}

The project undertook many outreach and training courses. The geographic position of the major areas of interest (Central and East Asia) was reflected by the high portion of project participants from developing countries, namely, China, Kazakhstan, Kyrgyzstan, Mongolia, Russia, Uzbekistan. In addition, participants from developing countries outside the CAOB (Bangladesh, India, Indonesia, Nepal, Thailand, Vietnam) were involved into its study. $85 \%$ of about 400 participants of the 2013 IGCP\#592-related meetings were from that category of countries. The IGCP\#592 training program for young scientists included eight field training and lecture courses.

1) Field training on mineral deposits in the Khivy-Sultan-Uvais area of Uzbekistan was held on April 26 - May 3, 2013. The training was supervised by Prof. Reimar Seltmann (Natural History Museum, London, UK). It involved nine participants from Uzbekistan, Norway and United Kingdom, all of whom had a good chance to study ore types from outcrop and core samples (Fig. 2a).

2) The field training on Ocean Plate Stratigraphy (OPS) on May 12-13, 2013 was supervised by Prof. Shigenori Maruyama (Tokyo Institute of Technology, Tokyo, Japan). The participants from Japan, Russia and the USA studied the Inuyama area of the Mino accretionary complex, central Honsu, Japan. The Inuyama area is a type locality of OPS showing a full OPS section from deepmarine chert to turbidite sandstones (Fig. 2b).

3) A seminar on the $\mathrm{CAOB}$ and western Pacific organized in the University of Tokyo, Tokyo, Japan, on May 29, 2013 (Fig. 2c). The seminar was supervised by Drs. T. Komiya and I. Safonova. Twelve participants from Japan and Russia presented 10 talks including key talks on i) continental construction in Pacific-type orogenic belts, ii) tectonic erosion in the Japanese Islands, iii) two-stage model of mantle thermal evolution and iv) mid-Permian South Kitakami accretionary belt.

4) A field training course on mineral deposits in East Kazakhstan held on June 15-30, 2013. The field targets were located within the Irtysh shear zone and Eastern Kalba metallogenic zone, near Oskemen, and at the Verkhnee Espe rare-metal REE deposit in the Zharma Saur tectonic zone. The training of nine participants from Kazakhstan and UK was supervised by Prof. Reimar Seltmann.

5) A round-table discussion on "Phenomenology of rifting at the example of the Baikal rift" for young scientists was organized in the frame of Meeting\#1 on August 23, 2013. The discussion was led by Prof. Sergei Rasskazov and highlighted major scientific problems of the regional tectonic and magmatism.

6) The 2013 Best Poster Challenge was traditionally scheduled during the $10^{\text {th }}$ IAGR Symposium (Meeting \#4). The challenge was held on October 2, 2013 and involved 34 post-graduate and $\mathrm{PhD}$ students from China, Japan and South Korea. Prof. Wilfred Winkler (ETS Zurich, Switzerland) was a head of the award committee. The awardees were Ms. He, Ms. Guo, Mr. Yi, and Mr. Li.

7) During October 6-19, 2013 Prof. Reimar Seltmann presented a short course on "Geodynamics and Metallogeny of Central Asia" to undergraduate students from the Kazakh-British Technical University in Almaty and supervised eight $\mathrm{PhD}$ students of the East Kazakhstan State Technical University, Oskemen, Kazakhstan (Fig. 2d).

8) The final training event was a lecture course on environmental problems connected with geological processes in Central Asia held during December 2-16, 2013. Prof. Sergey Krivonogov 

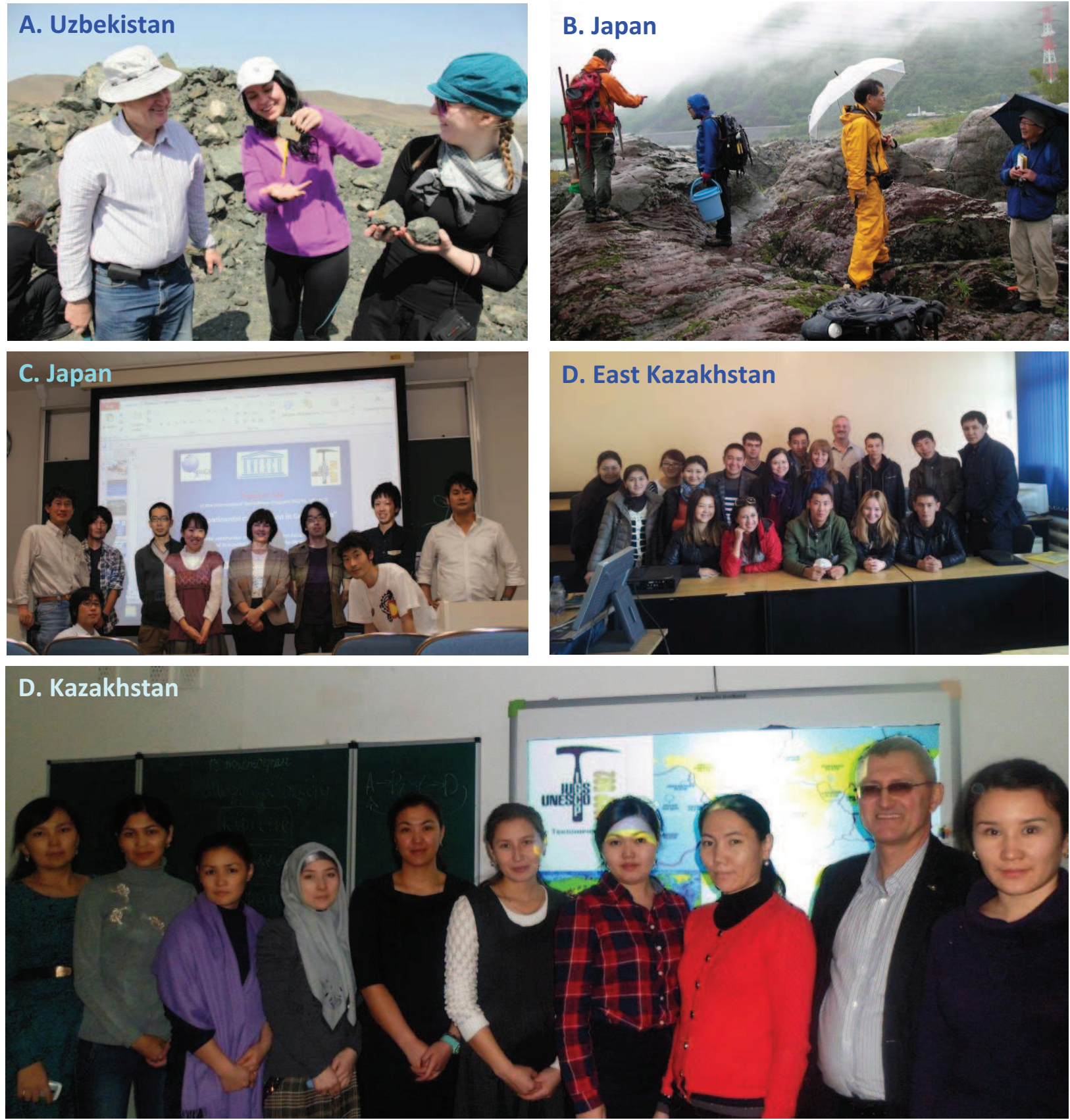

Figure 2. Photos from the 2013 field training and lecture courses for young scientists related to IGCP\#592. A - field training on mineral deposits in Uzbekistan; B - field training on OPS, Japan; C - seminar on the CAOB, Japan; D - lecture course on "Geodynamics and Metallogeny of Central Asia”, Kazakhstan; E - lecture course on climate changes, Kazakhstan.

supervised the course, which involved about 20 master and postgraduate students of the Kyzyl-Orda University pf central Kazakhstan (Fig. 2e).

\section{IGCP\#592 meeting plan for 2014}

Main goals of 2014 activities of the Project are aimed (i) to increase the impact of research and focus on high-quality meetings (six planned for 2014); (ii) to expand contacts in the Australasian region to enable comparison of CAOB with WP; (iii) to verify if accretionary processes operated as early as in the Archean; (iv) to determine whether crustal growth has changed since the Archean by evaluating the portion of juvenile crust by $\mathrm{Hf}$ isotopes of zircons and the portion of tectonically eroded TTG-type crust. For 2014 we plan the following meetings (http://igcp592.igm.nsc.ru/milestonemeetings):

1. The International Conference on "Continental Dynamics" and a field trip to the Qinling Orogenic Belt was organized by the Northwest University, Xi'an, China, 26-28April 2014 (http:// www.conferencenet.org/conference/iccd.htm). This meeting involved open discussion and exchange of ideas on a wide range of topics related to the formation and destruction of continents, cratons and supercontinents and their relationship to tectonics and deep mantle dynamics. A special goal of this event was to 
bring together geologists, petrologists, geochemists, geochronologists and geophysicists in integrating diverse approaches and methodologies.

2. The International Workshop "Convergent Margins" was organized by the Karadeniz Technical University, Trabzon, Turkey during 21-23 May 2014. The meeting program included a short course for students and a field trip to the eastern Pontides. The aims of the workshop were (i) to share the latest scientific database and models on convergent margins and related geological processes; (ii) to foster the active involvement of young earth scientists and to provide a common intellectual forum to discuss their research and ideas with experts; (iii) to encourage multi-disciplinary and international research collaborations. The workshop contributed to better understanding of the geological processes at convergent plate margins by attracting a wide-spectrum of earth scientists working on tectonics, petrology, ore genesis, oceans and life evolution (http://www.convergent margins.com/).

4. The XII International Platinum Symposium will be held in the Ural Federal University, Yekaterinburg, Russia, during 11-14 August 2014 (http://conf.uran.ru/default.aspx?cid=12ips). The scientific program includes oral and poster presentations at seven sessions: 1) magma dynamics, cumulates and ore genesis; 2) PGE mineralization in mafic-ultramafic intrusions of Russia: geology and petrogenesis; 3) PGE-Cu-Ni sulfide-bearing ultramafic-mafic intrusions of the Noril'sk Province: insights into ore genesis and exploration; 4) models and exploration methods for magmatic $\mathrm{Ni}-\mathrm{Cu}$-PGE sulfide and PGE-oxide deposits from around the world; 5) ophiolites and Ural-Alaskan-type intrusions; 6) PGE and $\mathrm{Au}$ through experiments; 7) new advances in the understanding of PGE mineralogy from magmatic to supergene environments.

4. The II International Conference «Granites and Earth's Evolution» with a field trip to the Russian Altai will be organized by the Institute of Geology and Mineralogy SB RAS, Novosibirsk, Russia (https://sites.googlegroups.com/site/igcp592/milestonemeetings/). The conference will be held during 17-20 August 2014 and focus on the following major topics: i) mantle and crustal sources of geochemically variable granitoid magmas; ii) geochemistry of granitoids and their hosting rocks; iii) granitoid magmatism and crustal growth; iv) mantle-crust interaction; v) syntectonic granitoid magmatism; vi) granitoids of Large Igneous Provinces; v) mineral resources of granitoids.

5. The $14^{\text {th }}$ Quadrennial Symposium "Mineral Resources: Discovery and Utilization" of the International Association on the Genesis of Ore Deposits (IAGOD) will be held in Kunming, China, on 19-22 August 2014 (http://www.14iagod.org/en/). The 14th Quadrennial IAGOD Symposium will provide excellent opportunities to present and exchange knowledge on research on the genesis of ore deposits to cover all aspects of currently hot topics in economic geology that will lead to an enhanced understanding of the genesis of mineral deposits in continental settings, as well as to improved techniques for exploration, discovery, and utilization. There are nine post-conference field trips planned: in Yunnan, Guizhou, Jiangxi and Shandong provinces of China, as well as in Vietnam and Laos.

6. The 2014 Annual Convention of the International Association for Gondwana Research (IAGR) and 11th international symposium on Gondwana to Asia will be held in China University of Geosciences Beijing (CUGB), China during September 20-
21, 2014 (http://www.iagrhomepage.com/zb_users/upload/2013/ 10/IAGR_2014_convention.pdf). The program of the conference will include a one-day workshop on establishing a Global Research Center, and a post-conference field excursion. The 2014 IAGR conference provides important opportunities to meet with renowned geoscientists, for exchange of scientific ideas and for the growth of excellence in academic and scientific pursuit. A wide range of topics related to supercontinent tectonics in general and Gondwana-Asia links in particular will be addressed.

\section{Conclusions}

1. The participants of Meeting \#1 concluded that: (a) continental rifting triggers volcanism, increased hydrothermal activity, tectonic activation, intensification of sedimentation, and formation of oil-and-gas and metallic mineral deposits in the CAOB; (b) Cenozoic rifting in Central and East Asia is linked to mantle plumes; (c) rifting-related magmatism contributes to crustal growth; (d) the Cenozoic rifting in Central and East Asia is still active.

2. The final session of Meeting \#2 touched on vital problems in interpretation of analytical data, necessity of field evidence for many models, quality of data, dating of deformation, OPS in accretionary complexes, geological, geophysical and geochemical evidence of mantle plumes.

3. The participants of Meeting \#3 agreed that the southern margin of the Siberian Craton, a major part of the CAOB, was a major place of crustal growth and formation of mineral deposits. This region of the $\mathrm{CAOB}$ should be a focus of future up-to-date studies including isotope geochronology, seismicity-related hazards and ore mineralization modeling.

4. The 2013 IAGR Symposium (Meeting\#4) helped IGCP\#592 to promote the major goals of our project: (i) the role of Gondwanaderived terrains in the CAOB (North China, Tarim, Kazakhstan, and their comparison with "true" Gondwana terrains, e.g., India, South Africa, Antarctica; (ii) the juvenile versus recycled crust in the CAOB and western Pacific (NE Asia, Japan, Korea).

5. The field trip associated with 2013 GSNZ Conference showed how complex relationships between different terranes outboard of arcs could be, yet how they could be solved with careful attention to details in mapping, sampling and laboratory work.

6. A major social impact of 2013 was high activity of women scientists, young scientists and scientists from developing countries. These categories of participants benefited from direct meeting attendance support, university seminars on CAOB and WP, field courses and lecture courses on mineral deposits. Eight field training and lecture courses widened the knowledge of many young geosientists and students about the $\mathrm{CAOB}$ and its possible and probable analogues in the western Pacific.

7. The six meetings scheduled for 2014 under the auspieces of IGCP\#592 indicate a widening coverage of project activities and consequently a growing number of scientists directly involved into multi-disciplinary and targeted collaborative studies of the Central Asian Orogenic Belt in comparison with their analogues in the western Pacific.

\section{References}

Glen, 2013. Refining accretionary orogen models for the Tasmanides of eastern Australia, Australian J. Earth Sci., v. 60, no. 3, pp. 315-370. 
Kim, S.W., Park, S.I. (Eds.), 2013. The 2013 IAGR Annual Convention and $10^{\text {th }}$ International Symposium on "Gondwana to Asia", KIGAM, Daejeon, South Korea, 1-4 October, 2013, IAGR Conference Series No. 14, Abstract volume.

Kröner, A., Kovach, V., Belousova, E., Hegner, E., Armstrong, R., Dolgopolova, A., Seltmann, R., Alexeiev, D.V., Hoffmann, J.E., Wong, J., M. Sun, Cai, K., Wang, T., Tong, Y., Wilde, S.A., Degtyarev, K.E., Rytsk, E., 2014. Reassessment of continental growth during the accretionary history of the Central Asian Orogenic Belt. Gondwana Research, v. 25, pp. 103-125.

Kusky, T., Windley, B., Safonova, I., Wakita, K., Wakabayashi, J., Polat, A., Santosh., M., 2013. Recognition of Ocean Plate Stratigraphy in accretionary orogens through Earth history: A record of 3.8 billion years of sea floor spreading, subduction and accretion. Gondwana Research, v. 24, pp. 501-547.

Lee, Y.S., Kim, S.W., 2014. International Association for Gondwana Research (IAGR) 2013 Annual Convention10th International Symposium on Gondwana to Asia. Conference report. Gondwana Research, v. 25, pp. 873-875.

Mortimer, N., Gans, P.B., Calvert, A.,Walker, N.W. 1999. Geology and geochronometry of the east edge of the Median Batholith (Median Tectonic Zone): a new perspective on Permian to Cretaceous crustal growth of New Zealand. The Island Arc, v. 8, pp. 404-425.

Rasskazov, S.V., Nikishin, A.M., Primina, S.P. (Eds.), 2013. Continental rifting, accompanying processes. Proceedings $2^{\text {nd }}$ Symposium. Institute of Earth's Crust SB RAS, Irkutsk, Russia, August 20-23, 2013.

Safonova I., Seltmann R., Sun M., Kroener A., Kislov E., Kovach V., Collins V., 2013. Continental construction in Central Asia (IGCP592): scientific results and meetings in 2012. Episodes, v., 36, pp. 227-234.

Safonova, I., Seltmann, R., Kroener, A., Gladkochub, D., Schulmann, K., Xiao, W., Kim, T., Komiya, T., Sun, M., 2011. A new concept of continental construction in the Central Asian Orogenic Belt (compared to actualistic examples from the Western Pacific). Episodes, v. 34, no. 4, pp. 186-194.

Song, D., Xiao, W., Han C., Li, J., Qu, J., Guo, Q., Lin, L., Wang, Z., 2013. Progressive accretionary tectonics of the Beishan orogenic collage, southern Altaids. Precambrian Research, v. 227, pp. 368-388.

Tian Z., Xiao W., Shan Y., Windley B.F., Han C., Zhang J., Song D., 2013. Mega-fold interference patterns in the Beishan orogen (NW China) created by change in plate configuration during Permo-Triassic termination of the Altaids. Journal of Structural Geology, v. 52, pp. 119135 .

Tsygankov, A.A., Kislov, E.V. (Eds.), 2013. Geodynamics and Formation of Mineral Deposits in North-East Asia. Proc. of the $4^{\text {th }}$ conference, Geological Institute SB RAS, EKOS, Ulan-Ude.

Xiao, W.J., Zhang, Z., Safonova, I., 2013. International Field Trip and Workshop "Beishan Orogen in NW China: accretionary tectonics, magmatism, eclogite and granulite complexes. Episodes, v. 36, pp. 295-297.

\section{CALL FOR NEWS ITEMS FOR THE IUGS WEBSITE}

The IUGS Publications Committee aims to improve the Union's website. The home page already carries brief News items. To improve this feature, we require regular news items to appear on a rolling basis. These will be held on the page for 10 days before being archived.

To meet our objective we need you, the IUGS community, to provide items that you think will be of wider interest. These might relate to forthcoming events (international, national, or regional), the outcomes of events, new major publications, progress on initiatives such as Geoparks or IGCP projects or notices of significant geoscience advances.

Contributions should not exceed about 120 words but may contain links to relevant background information including illustrations, etc.

WE DEPEND ON YOU TO MAKE THIS A SUCCESS! The transition will begin within the next few weeks. 